$\pm N / N$

Global Journals Inc.

की

\title{
Film Marketing Technique in Bangladesh: Is Youtube Trailer the Most Effective Tool?
}

By Shaolin Shaon

University of Dhaka

Abstract- In recent times, the film industry is becoming precisely phenomenon worldwide. But formerly gathering knowledge about this specific issue, film marketing theory,strategy, policy, and hierarchical procedure should maintain while practising. The research undertakes the historical analysis of films from the very past, several marketing policies and practice of Bangla movies and tries to identify their strategy of marketing. The questionnaire includes in-depth interviews of the audiences, and the sampling procedure is purposive sampling. The samples collected throughout the study explores the ethical issues of the essential film marketing techniques. Drawing on, the uses and Gratifications model of Active Audience Theory, this study discovers the methods and conclude that YouTube Trailer is the most compelling film marketing technique. Therefore, identification of the marketing strategy is supportive of the film to be blockbuster or successful in the theatre, and marketing of a movie generates countless impact to be widespread in the audience.

Keywords: the film industry, film marketing, film marketing techniques, active audience, youtube trailer.

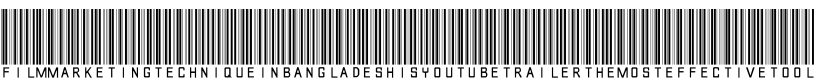

Strictly as per the compliance and regulations of:

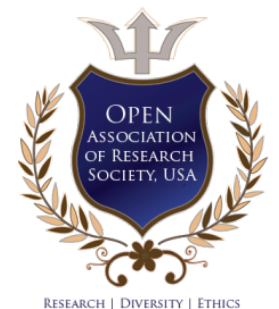

(c) 2019. Shaolin Shaon. This is a research/review paper, distributed under the terms of the Creative Commons AttributionNoncommercial 3.0 Unported License http://creativecommons.org/licenses/by-nc/3.0/), permitting all non-commercial use, distribution, and reproduction in any medium, provided the original work is properly cited. 


\title{
Film Marketing Technique in Bangladesh: Is Youtube Trailer the Most Effective Tool?
}

\author{
Shaolin Shaon
}

\begin{abstract}
In recent times, the film industry is becoming precisely phenomenon worldwide. But formerly gathering knowledge about this specific issue, film marketing theory, strategy, policy, and hierarchical procedure should maintain while practising. The research undertakes the historical analysis of films from the very past, several marketing policies and practice of Bangla movies and tries to identify their strategy of marketing. The questionnaire includes in-depth interviews of the audiences, and the sampling procedure is purposive sampling. The samples collected throughout the study explores the ethical issues of the essential film marketing techniques. Drawing on, the uses and Gratifications model of Active Audience Theory, this study discovers the methods and conclude that YouTube Trailer is the most compelling film marketing technique. Therefore, identification of the marketing strategy is supportive of the film to be blockbuster or successful in the theatre, and marketing of a movie generates countless impact to be widespread in the audience.
\end{abstract}

Keywords: the film industry, film marketing, film marketing techniques, active audience, youtube trailer.

\section{InTRODUCTION}

ilm marketing is a trendy term and considered as a critical piece of a film's prosperity. At the point when a film goes into creation, it should be nurtured like some other item and get the group of onlookers eager to see it. Dr Philip Kotler (2003) defines marketing, as the science and art of quantifying the size of the target market and promoting the appropriate products to satisfy the needs of the customer at a profit.

The promotion is known as film marketing and people responsible for this, belong to the production house of the film. Consequently, film marketing is concerned with how production houses position the film within the minds of the audience to encourage consumption of their movie. Through some useful techniques, the purpose of film marketing is to convince the audience about buying tickets to watch a film in movie theatres. As a result, film marketing techniques are some tools which aim to promote a movie to its target audience. This research will explore the various methods of film marketing in Bangladesh and also find the most compelling film marketing technique in Bangladesh.

\section{a) History of Film Marketing in Bangladesh}

To contextualize this research, it is necessary to have a brief overview of the film marketing history of

Author: MSS (student), Department of Television and Film Studies, University of Dhaka, Bangladesh.e-mail: shaontfp@gmail.com
Bangladesh. Early film marketing techniques were a poster, banner, leaflet, newspaper advertisement, magazine advertisement, lobby card, and press card (Hossain \& Sultana, 2016).

History of film marketing in Bangladesh is interrelated with the advancement of Bengali film. The history of Bengali film refers to the- films produced in British-ruled undivided Bengal till 1947, films produced in East-Pakistan period till 1971 and the early films of Dhallywood- the present Bengal film industry of Bangladesh (Qader, 1993). In 1900, Hira Lal Sen made two advertisements -on Jabakusum Hair Oil and Edwards Tonic - and became the first Indian, to use film for advertising purposes (Bandopadhyay \& Alexander, 2017). As advertising is a subset of marketing (McCall 2002), it should not be wrong to call it- the beginning of marketing in West-Bengal films.

Looking at the progression of West-Bengal films, in 1931, East-Bengal produced a silent movie- The Last Kiss (Hossain \& Sultana, 2016) and in 1947 after being East-Pakistan, produced its first

The Bengali-sound film "Mukh O Mukhosh" in 1956 (Quader, 1993). Suvash Datta designed posters of "Mukh O Mukhosh" (Hossain \& Sultana, 2016). Usually, these posters contained images with necessary texts- film title, names of the cast, director, production house; the release date- and become one of the vital film marketing technique to attract an audience for watching the film in theatres.

In 1913, the bioscope exhibition of Armatitola Jute Warehouse in Dhaka gradually converted into the first movie-theatre of Bangladesh -the "Picture House" which became "Shabestan Hall" later (Razu, J., 2000). In 1920 , this movie-theatre was officially inaugurated and displayed posters inside and on the outside of movietheatre, and elsewhere on the street or in shops as a film marketing technique (Hossain \& Sultana, 2016, p.14). Posters called the attention of the target audience, and the audience got hints of the film story by the colour, depth, angle, and language on a poster. (p.15).

Hosssain and Sultana (2016) also found posterbased film marketing changed over time. The posters of the 1960s were black-and-white. Usually, it located stillimages of the cast in the centre and exhibited more spaces in the background. The signs of the 1970s showed motion in the images of the cast and placed it in an abstract background. The colour ful posters were 
introduced in 1980 and gave priority to the clothing, jewellery, hairstyles, and make-up of cast. Along with heroes, villains also appeared in 1990s poster (pp. 1416).

Whether its hero, heroine or villain; the face of the cast in poster also began to convince the audience in watching films and "the notion of "star" emerged in the 1980s through it" (Eastman, 2000, p.239). The star power of Abdur Razzak, Kabori Sarwar, Shabana, Farida Akhter Bobita, Farooque, Shabnam, Kohinoor Akhter Shuchanda, Alamgir, Sohel Rana, Bulbul Ahmed, Zafar lqbal, Wasim, llias Kanchan, Jashim, Rozina, Parveen Sultana Diti, and Champa was portrayed through film poster and considered as a film marketing technique. Faces of Stars on a poster influenced the audience to watch the film in the theatre.

The poster also used in another film marketing

technique that is, microphone publicity of films. Microphone publicity referred a van with the sound system- fully covered with film posters - used to travel in various areas by the van-puller with a recorded audioannouncement of an upcoming film or sometimes with a narrator in a van who supposed to announce the news of film on the microphone (Moti, 2016). In the van, the narrator used to pronounce "Asiteche" exaggeratedly! "Asiteche" (Bengali words which meant "coming soon") on the microphone to call the attention of the audience about the upcoming film (Nihad, 2013). This technique of film marketing was influential among the audience as it provided information like- the names of actor-actress and director, release date, available movie-theatres; movie-show time, ticket price etc. (para. 2). Songs of that upcoming film were also played in these vans to attract audience about the film (Moti, 2016).

Film-songs played on Radio shows, were another popular film marketing technique that convinced the audience to watch the film in theatres. In 1927, stateowned radio station, Bangladesh Betar started broadcasting shows on film-songs - "Onurodher Asor: Ganer Dali", "Tibbet Snow Tarokar Sondhane", "Clinic Plus Surer Dipti", "Sunlight Sangeetmala", "Rokomari Ganer Onusthan Geetali" etc. (Muktadir, 2012). Before playing film-songs, the host of the show used to state the names of the singer, musician, songwriter - along with the films name and its actor-actress, director, release date, available movie-theatres, movie-show time etc. (para.4). Influenced by these film-songs played on Radio shows, the audience becomes curious to watch that film in movie-theatre.

Besides Radio, in 1964, state-owned television channel Bangladesh Television (B.T.V.) become a popular place for film marketing. "Chaya-Chondo" was a popular show of film-songs that also provided information about the films name and its actor-actress, director, release date etc. (Zahid, 2017). While radioshows only provided the audio-version of a film-song, Television shows provided the visuals too. That's why the audience was highly influenced by the film marketing done through television-shows like "Chaya-Chondo".

Once the film has been in theatres for a week, newspapers and magazines started reviewing the film. In 1900, Hinduranzika- the weekly magazine of Rajshahi, published a review on the bioscope show held in the house of Sarail Kumar Roy, the Boalia Zamindar of Rajshahi City. This magazine review made curiosity in people to go and watch it (Bagchi 2008). So then, salient features published in the entertainment section of newspapers and magazines worked like a film marketing technique to attract an audience for watching the film in the theatre.

Although the film marketing techniques applied in the past are different from the present film marketing context, the consistency and pattern are almost the same with that era.

\section{b) Significance of the Study}

Occasionally a good story and a spectacular appearance of stars in a film would not be enough to expect excellent performance in box-office without a proper film marketing plan. Film promoting process can have a significant effect on whether or not it is successful. Movies are expensive to make, and if the audience does not buy tickets to watch the film in the theatre, the production house lost a lot of money. So, it is necessary to conduct film marketing research to find out the practical techniques of film marketing that convince the audience to watch films in the theatre.

The decreasing number of movie-theatres in Bangladesh demonstrates the dropped-down of film watching. It is the urgent duty of the production houses to invent something new in their film marketing plan to bring the audience back in movie theatres. In spite of this situation, films like "Aynabaji (2016)", "Dhaka Attack (2017)" have brought the audience in movie-theatres. The marketing technique of these films is considered an essential reason for their commercial success. So this study has tried to locate the appropriate marketing techniques for Dhallywood film.

Thus, in Bangladesh, what are the proper film marketing techniques and which one is the most compelling film marketing technique that brings the audience back in movie-theatres- are the goal of this research.

\section{c) Literature Review}

This section assesses the critical scholarly works on film marketing. The principal arguments, methodologies, and limitations of these texts are discussed in this part to explore and find out the gaps. Since there is no research on film marketing techniques in Bangladesh, works done in other countries are examined here.

Chattapadhay and Chaudhury (2014) worked on exaggerated film promotion of Bollywood. The study was conducted based on a questionnaire survey. 
Among 80 respondents, $90 \%$ of them believed that without advertising, none of any films would do well. The promotion of Bollywood films has become more critical to producers than developing scripts. Actress Rani Mukherjee appeared in various television shows to promote her film No One Killed Jessica. Affair-rumours between stars are seen intentionally before the release of their film as a film marketing technique (pp. 1-3).

Dutta and Majumder (2014) have worked on a case study on the marketing success of Tollywood films. Tollywood is a portmanteau of the words Tollygunge and Hollywood-referred as the cinema of West Bengal (Kanapaka, 2013). Dutta and Majumder analyzed some selected films -'Chader Pahar', 'Ovishopto Nighty', 'Bengali Babu English Mem', 'The Royal Bengal Tiger', and 'Taan'. The weekly collection and total box-office earnings of these films were elaborately explained (pp. 259-263), but the study did not disclose the marketing techniques of these films.

While Dutta and Majumder (2014) analyzed the marketing success of particular films; Bohra, Sinha and Ajit (2016) investigated the marketing strategies of a renowned Indian production house, Red Chilies Entertainment. They also used case study methods like Dutta and Majumder. Bohra et al. (2016) found that in spite of having poor scripts, some films of Red Chilies production like - Chennai Express, Happy New Year, Dilwale- ensured a profit in Box-office collection. He credited the marketing techniques of these films which lured away audience to watch it in movie theatres. Red Chilies Entertainment spent 40 crores for the marketing of Ra-one, which was half of the entire film's budget. The trailer of Ra-one was launched in 36 cities worldwide (pp.1-2). This production house also created a website, started a game apps "Ra-one" and let the audience live chat with the lead cast Shahrukh Khan through Google live chat, affiliated with brands like Western Union to make effective marketing of their films (pp. 3-4).

Arun Madhusudhanan (2012) studied the overall Indian film marketing history, marketing techniques, and marketing strategies. Mainly, he did a textual analysis on the brief overview of

Indian film promotion. In the chapter- 'film marketing techniques,' he analyzed trailers, television advertisements, posters, audio launch, websites, merchandising, street marketing, and radio promotion (pp. 17-29).

In Iran, Mohammadian and Habibi (2012) studied the impact of the marketing mix on attracting audiences to the movie theatres. A questionnaire survey made the study more comfortable, and they applied '4Ps model' - Product, Price, Promotion, and Place- of marketing in this study. The study found the place was the most influential variable in attracting an audience, the product was the second variable, and the promotion was third and finally came a price. They showed that seven types of film promotion were influential in attracting an audience to movie-theatres word of mouth, movie reviews, television commercials, press advertisements, posters, radio advertisements and film website (p.104).

While film promotion was a minor part in Mohammadian and Habibi's research, Timothy Cheng (2014) did an elaborate content analysis on films promotion techniques, and it's importance in New York State. He found the importance of promotion in three stages -pre-production, production, and postproduction- of a film. Pre-production film marketing techniques were audience research, typecasting, test screening, merchandising, and promotional tie-in (pp.11-21). Film marketing techniques of production stage were traditional tactics -based on print media and audiovisual tactics -based on the internet (pp. 22-30). Cheng also explained that conventional film promotion techniques are print media - news releases, feature stories, cast and crew details, director's statement, posters. A 2000 research by Eastman found audiovisual film marketing include promotional tours, media interviews, video news releases, and web pages (cited in Cheng, 2014, p. 25). Critics review and attention in award shows were the post-production film marketing techniques (pp. 31-38). Though these film marketing techniques discussed, this study did not identify the most feasible film marketing technique in New York.

$$
\text { According to the International }
$$

Telecommunications Union (2015), more than 3.2 billion people are now using the Internet. So, digital media will rule the contemporary film marketing techniques. Schorr and Angela (2003) categorized digital marketing into two types- Internet Marketing (web, smart phones, email marketing, online banner advertising and Social Media) and Non-Internet marketing (television, radio, SMS, digital billboards). They also identified that the latest buzzword in digital film marketing is Social media, such as Facebook, Twitter, Google+, Instagram, and YouTube. Another facility is, social media costs less than traditional marketing campaigns (Wheaton, 2011).

Boyd and Ellison (2007) described Social media and its characteristics:

"Social media is web-based services; that allow individuals to (1) construct a public or semi-public profile within a bounded system, (2) articulate a list of other users with whom they share a connection, and (3) view and traverse their list of connections and those made by others within the system (Boyd \& Ellison, 2007, para. 5). "

By conducting primary research via surveying 154 college students and gathering secondary data, Jerrick (2013) found YouTube trailers effectively encourage and influence college students to buy tickets and watch the film in the theatre. Sannapu, Parihar, Kandwal, and Kakkar (2014) also identified YouTube trailer as a foundation of success in their study on the 
importance of web-based tools for the promotion of movies. They found maximum customer attracts through a YouTube trailer of a film.

Finally, this study will try to see film marketing techniques in Bangladesh and also will try to find the most feasible film marketing technique in Bangladesh.

\section{il. Research Questions}

- What are the film marketing techniques used in Bangladesh?

- Which one is the most effective film marketing technique in Bangladesh and why?

\section{a) Theoretical Framework}

This study uses "Active Audience Theory" as its theoretical framework. In the quest for the question "How to measure an active audience?" Blumler (1979) suggested the engagement of audience with media in several ways- utility (specific media for specific tasks), intentionality (prior motive determinates the press), selectivity (selection of media is reflection of individual interest) and imperviousness to influence (the construction of own meaning from media content) (West, Richard \& Lynn H. 2010).

One of the compatible models of "Active Audience Theory" is the Uses and Gratifications Theory. This theory examines the relationship between how people use the media and the gratification they seek from their media behaviours. This study preferred Uses and Gratifications Theory because of its priorities audience who are aware of consuming various media content. The audience is not only passive consumers of media but also have power over their media consumption.

In 1969, American theorist Jay Blumler and British theorist Denis McQuail developed Uses and Gratifications Theory (UGT). They found, the election of 1964 in the United Kingdom, led people to watch political programs on television. After studying these audience motivations, they formed the foundation for their research in 1972.

Robin L. Nabi and Mary Beth Oliver (2009) noted the media observation of uses and gratification researchers:

"Uses and gratifications researchers have examined media; like (a) a variety of traditional mediatelevision, radio, newspaper, music, and movies; (b) different media contents such as - news, soap-operas, sports; and (c) emerging media including video cassette recorders, television remote controls, personal computers and the internet. (p.148) "

Lasswell (1948) suggested media has the functions of surveillance, correlation, entertainment, and cultural transmission. These functions were extended by Blumler, McQuail and Brown into four groups: diversion (escape from problems and emotional release), personal relationship (substitution of media for companionship), own identity or individual psychology (selection of media is reflection of particular interest) and surveillance (information about factors which might affect one to accomplish something) (Blumler, 1979).

In 1973-74; Michael Gurevitch, Hadassah Haas, and Elihu Katz joined Blumler, Brown, and McQuail to conduct collaborative research on how people viewed mass media. Katz, Blumler, and Gurevitch (1973) gave five underlying assumptions in uses and gratification theory:

Five underlying assumptions consistent with uses and gratification theory; Audience is active, and its media use is goal-oriented, gratification and media choice lies with audience, media compete with other sources of satisfaction, audience is aware of their media use, interests, and motives; the audience can only assess value judgments of media content.(pp. 16-17)

Katz, Blumler, and Gurevitch also took literature on the social and psychological functions of the mass media, developed 35 needs and put them into five categories- Cognitive Needs, Affective Needs, Personal Integrative Needs, Social Integrative Needs and Tension Release Needs.

Cognitive needs refer that people use media for acquiring knowledge, information, and understanding (Katz, Blumler \& Gurevitch, 1973). Television (news, quiz programs to gain experience and data), video (how-to), and documentaries fulfil the cognitive needs of the audience (Lorenz, 2011). Affective needs include all kinds of emotions, pleasures, feelings and other moods of the audience (Katz et al. 1973). Emotional scenes or comedy scenes in movies; soap operas, sitcoms on television are suitable examples of affective needs (Lorenz, 2011).

Personal integrative needs represent credibility, stability, status etc. (Katz, Blumler \& Gurevitch, 1973). By watching media (advertisements) like - jewellery advertisement, furniture's advertisement- audience get to improve their lifestyles. After buying these products, audience stabilizes their status with the help of media (Lorenz, 2011). Individual integrative needs are the need to socialize with family, friends, and relations in society (Katz et al. 1973). Media products can produce a frequent topic of conversation among people like- who is going to win the X-factor contest of MTV (Abbiiti, 2014). Nowadays, People uses social media likeFacebook, Instant Messaging, Chat Rooms, Instagram, Skype, Viber, and Whatsapp etc. to arrange a gettogether. Another example is, watching a particular serial or film will create common topics for discussion among friends. If one fails to participate in this conversation, people will criticize.

To relieve tension, People often depends on media which is a mean of escapism (Katz, Blumler \& Gurevitch, 1973). Abbiiti (2014) noted an example that, some watch news to relax, and some get more tension by watching the news-the program is the same and 
people use it for different needs. So, the requirements are individualistic. Through Computer games and action films, viewers escape from their real lives and imagine themselves in that situation. Based on active audience theory, this study defines the audience as active viewers who consciously look for media outlets to fulfill their need for information related to upcoming films.

\section{ili. Methodology}

Qualitative Approach was taken into action while conducting the study. For understanding how a community or individuals within it perceive a particular issue, then qualitative methods are often appropriate (Patton \& Cochran, 2002).

\section{a) Data Collection \\ In-depth interviews of the audience are used to} collect data about their choices. In-depth interviews are useful when the detailed information about a person's thoughts and behaviours or exploration of any issues profound in needed (Boyce \& Neale, 2006). The interviewees were selected based on purposive sampling. Purposive sampling is done, based on the characteristics of a population and the objectives of the study decided by the researchers (Crossman, 2018). Twenty-five people who watch Dhallywood film regularly were selected based on sex, age, educational qualification, and income.

\section{b) Data Analysis}

The interview data were analyzed by using thematic analysis process. Maguire and Delahunt (2017) found that "Thematic Analysis is the process of identifying themes within qualitative data" (p. 3352).

\section{"Six step framework is the most influential approach in the thematic analysis; these six steps are - become familiar with the data, generate initial codes, search for themes, review themes, define themes and write up. The first step in any qualitative analysis is reading and re-reading the transcript. (pp. 3353- 3355) "}

Transcripts were revised, and at this stage, rough notes were in the process of making. After becoming familiar with the data, the following step "generate codes" started. Coding is the process of organizing and sorting data (Coding Qualitative Data, para 2). Open coding, which means there are no pre-set codes but the coding process can modify the scenario (Coding Qualitative Data, para 8). Every transcript was coded separately to generate new codes and sometimes existing ones were modified. This process was done manually -with pens and highlighters - without any qualitative data analytic software. In the next step, the codes searched for themes. Some of the systems were associated with one idea and some with more than one. After developing preliminary issues, they were reviewed to consider whether the data did support it. The final refinement of this process is defining last themes "to identify the essence of what each theme is about" (Braun \& Clarke, 2006, p 92) (Braun \& Clarke, 2006, p 92).

The preliminary themes of data analysis-factors for watching a film in the theatre, traditional film marketing techniques, internet-based film marketing techniques, non-internet-based film marketing techniques, others unique film marketing techniquescondensed into a broader theme -Film Marketing Techniques in Bangladesh. Another two more general issues were - Most Effective Film Marketing Technique and Salient Features of That Most Effective Film Marketing Technique. These themes and codes are discussed in the 'findings' section elaborately.

\section{FINDINGS}

According to the research objective, this section states the output of data analysis. The objective of this study was to discuss the film marketing techniques in Bangladesh and also to identify the most effective film marketing technique in Bangladesh. Along with these key findings, this section also depicts others findings with the help of aforementioned themes and codes.

The preliminary themes of data analysis werefactors for watching a film in the theater, traditional film marketing techniques, internet-based film marketing techniques, non-internet based film marketing techniques, others unique film marketing techniques. 'Factors for watching a film in theater' refer to what are the factors which make sure that the audience will decide to watch a film in the theater. According to the interview data, this theme includes several codes favorite director (three interviewees were influenced by it), favorite star (three interviewees were influenced by it), word of mouth (eight interviewees were influenced by it), YouTube trailer (fifteen interviewees were influenced by it), Facebook review (two interviewees were influenced by it) and film-song.

'Traditional film marketing techniques' refer mainly to the digital but non-internet based film marketing techniques. According to the interview data, this theme includes several codes - microphone publicity (seventeen interviewees cited this), poster (seven interviewees cited this), radio shows of Bangladesh Betar (five interviewees cited this), rickshaw- painting (two interviewees cited this), filmsong show in Bangladesh Television (BTV) (one interviewee cited this). According to the interview data, the theme 'non-internet based film marketing techniques' include several codes - newspapers entertainment page (twenty-two interviewees cited this), television shows (seventeen interviewees cited this), FM Radio shows (six interviewees cited this), Entertainment News Bulletins (one interviewee cited this). Due to 
similarities, both of the themes -'Traditional film marketing techniques' and 'non-internet based film marketing techniques'- are merged and discussed elaborately in the discussion section of this research.

According to the interview data, the theme 'Internet-based sources of film marketing' include several codes - YouTube trailer (twenty-five interviewees cited this), Facebook pages of production houses (twenty-four interviewees cited this), Facebook check-in (eighteen interviewees cited this), Facebook film review group (eighteen interviewees cited this), ElectronicNewspaper (six interviewees cited this), Film Blogs (three interviewees cited this), Google search (three interviewees cited this), Celebrity's Social Media Activities (two interviewees cited this), BMDB- Bangla Movie Database (two interviewees cited this). Condensing the Codes in this theme can be condensed into YouTube, Facebook, Film blogs and ElectronicNewspaper.

According to the data analysis, the theme 'others unique film marketing techniques' include several codes - negative marketing through rumors (three interviewees suggested this), promotion in live sporting events (one sports-journalist interviewee suggested this), theme-based promotion (one advertisement-maker interviewee suggested this), promotion in wedding ceremonies (one student interviewee suggested this), merchandising with fashion brands and promotional tie-ins (one film-school-student interviewee suggested this), game apps launching (one freelancer interviewee suggested this) and one interviewee also suggested "casting Shakib Khan in Indo-Bangla Joint production films' is effective film marketing technique for both Bengali audience.

All of these aforementioned preliminary themes and condensed into a broader issue: Film Marketing Techniques in Bangladesh - which is the first objective of this study.

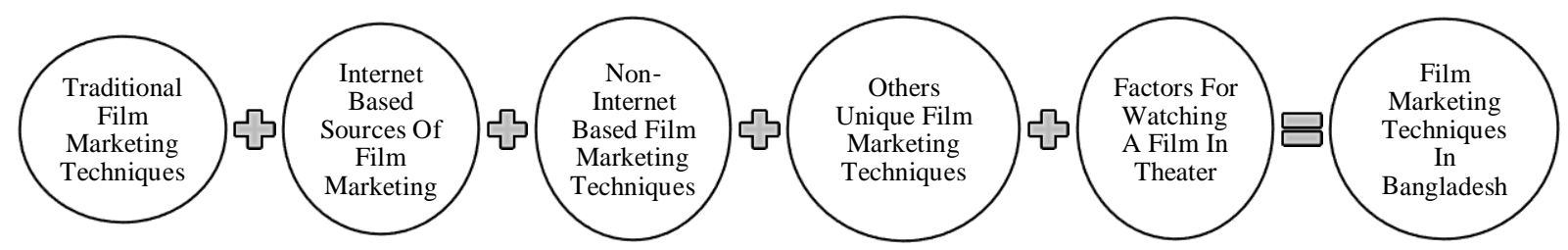

\section{Figure 1: Preliminary Themes Condensed Into a Broader Theme}

All of these among all interviewees, the 30 aged interviewees emphasized on traditional film marketing techniques like- poster, microphone publicity, radio shows, television shows, a newspaper advertisement and word of mouth. Others Interviewee who lived in the hostel did not have easy access to television and newspaper. That's why, to know about upcoming films, all of them were dependent on internet-based film marketing. Interviewees who lived with family had both access to non-internet based media- television, newspaper and internet-based media- YouTube, Facebook. Mentioned preliminary themes and condensed into a broader issue: Film Marketing Techniques in Bangladesh - which is the first objective of this study..

To mention merchandising and promotional tieins- one female interviewee expected that if "Along" (a brand of Bangladesh) sponsored costume of any film, she will definitely buy the dresses and also the film's ticket. The star cast of "Aynabaji" promoted the film in a live sporting event, which was one of the influencing marketing techniques for a male interviewee to watch this film in the theatre.
Fortunately, one advertisement maker informant gave an interview, and after mentioning YouTube the trailer, he emphasized the theme-based promotion of film marketing in Bangladesh. He gave an example of the film "Lal Tip". Imon and Kushum Shikder, the cast of the film "Lal Tip" executed their marketing plan in several universities and distributed Lal Tip (a women fashion object in Bangladesh) among female students. Another theme-based film marketing technique is launching game apps. One interviewee regrets that "Bijli" - the first-ever Super-hero film in Bangladesh - should have released a game app.

A unique film marketing technique, suggested by one student interviewee- was promoting films in the wedding ceremony. He gave an example of the song 'tui local bus' which he heard in a wedding ceremony where people were dancing on it. After returning hostel, he made a YouTube search for this song and enjoyed to listen to it. So, he proposed that if people performed on the songs of upcoming Dhallywood films in wedding ceremonies, it could be promoted.

Another unique film marketing techniquesuggested by one interviewee is- casting Shakib Khan in Indo-Bangla joint-production films. For his popularity in 
both Kolkata and Dhaka. His new fashionable look and hairstyle become a curiosity for him to watch filmsShikari, Nabab, Chaalbaaz, Vaijaan Elo re etc. Through YouTube Trailers, he liked Shakib Khan's performance in these films and later watched these films in theaters, while he did not watch Shakib Khans other home production films. According to him, Shakib Khan's new fashionable look in these Indo-Banglajoint production films was an effective marketing technique to drive the audience in the theater.

Alike he, "Favorite Star" is also a factor for another female interviewee to watch a film in the theater. Production houses usually cast the actor who is at the top of the audience's demand like- Shakib Khan, Arefin Shovo, Porimoni, and Mahiya Mahi in Dhallywood. In using star -power as a film marketing technique, typecasting is a marketing obstacle which occurs when a performer used to cast based on their previous performances, creating a style of character linked to their persona (Marich, 2005, p. 22). In Bangladesh, Producers cast Chonchol Choudhury and shakib Khan for parallel and commercial films respectively. The audience has never seen Chonchol Choudhury in a commercial one as well as Shakib Khan in a parallel film. They are seeing a particular face for a particular genre and got bored. To break down the typecasting, change of roles of the popular actors may be an attracting marketing technique for the audience. Porimoni who is an actress of commercial Dhallywood film- performed in a parallel film Shopnojal and broke the typecasting. After watching her new look in the YouTube Trailer of Shopnojal, many of the interviewees were influenced to watch this film in theaters.

Interviewees' makes an argument over the marketing techniques of parallel films. In the report "Bangla director focuses on Kolkata and Nawaz for the international film" by Times of India, stated that, after exhibiting in foreign countries, some of the directors directly prefer "World Television Premiere" in various television channels. That happened with films like Matir Moina (2002), Runway (2010). While commercial films have a bad reputation of containing vulgar contents, parallel ones are the case where it raises voice against the odds of society, government, history, religion, and politics. These are sensitive issues in a conservative country like ours, as our audience is not categorized still (Masud, 2011). That's why parallel films got banned from running their promotional activities in their own country despite praises from foreign film festivals. Overall, this foreign-film-festival based film marketing technique is also unique to attract a selected audience.

Informants also talked about the cynical marketing of films based on rumours. Nine informants in this research did not prefer this. This type of misguided marketing audience intentionally. Video news releases (VNRs) on YouTube like- "Dekhun Video Soho" is one kind of cynical marketing.
Informants' emphasized, negative marketing is lame and a waste of time. Temporarily, it may work as an effective film marketing technique, but it's not that in the real sense. Sometimes clicking on those Video News Links, people got hacked. It is rare to see the number of the actual video news release (VNR) about Dhallywood on YouTube. So, according to nine informants, negative marketing as a process of film promotion should be avoided.

Another two broader themes were - Most Effective Film Marketing Technique and Salient Features of That Most Effective Film Marketing Technique.

According to the interview data, the second theme 'Most Effective Film Marketing Technique' includes several codes- YouTube Trailer (eleven interviewees cited this), Facebook (seven interviewees cited this), Newspapers Entertainment Section (two interviewees cited this), Favorite Star Cast, Celebrity's live performance, Poster, Television Shows, Bangladesh Television (BTV) programs and word-of-mouth. YouTube Trailer was cited most among these codes. So then, YouTube Trailer is the most compelling film marketing technique in Bangladesh.

According to the interview data, the third theme 'Salient Features of That Most Effective Film Marketing Technique' states the reasons for preferring YouTube Trailer by observing the view of all the interviewees. The idea is, YouTube Trailers make the story of the film predictable to the audience. It exhibits attractive portions of a movie like romantic scenes, action scenes, locations, songs, the new look of casts, acting skills of cast etc. So, it becomes easier for the audience to judge the film and make a decision about whether they will watch the movie in a theatre or not.

\section{Discussion}

This section elaborates the findings of the study according to research objectives. Film marketing techniques in Bangladesh and the reason behind preferring YouTube Trailer as the most compelling film marketing technique is the two parts to highlight the discussion of the results.

\section{a) Film Marketing Techniques used in Bangladesh}

Traditional film marketing techniques of Bangladesh were mainly the non-internet based sources (Steinberg,2016) like- poster, banner, leaflet, view-card, lobby card, press card, newspaper advertisement, magazine advertisement, microphone publicity, rickshaw painting, Bangladesh Betar (Radio) shows, Bangladesh Television (B.T.V.) programs, etc.

Film marketing in Bangladesh started with a poster. In 1920, the first movie-theatre of Bangladesh "Picture House"- was officially inaugurated and provided information about upcoming films through advertisements (Raju, 2000). Film posters displayed all over movie theatres, and elsewhere on the street or in 
shops. Signs called the attention of the target audience, and the audience got hints of the story by the colour, depth, angle, and language on a billboard. Suvash Datta started designing a poster of "Mukh O Mukhosh" (Hossain \& Sultana, 2016). He also made varieties of signs like -show card and title card of "Mukh O Mukhosh". Title cards (also known as intertitles) are a piece of filmed, printed texts used to convey characters dialogue and to provide a detailed description on the screen (Chisholm \& Brad, 1987). Showcards can be in the form of words, numbers, scales, pictures, or other graphical representations of the film (Lavrakas, 2008).

Whether its hero, heroine or villain; the faces of the cast in posters also began to convince audience for watching films in movie-theaters and "the notion of 'star' emerged in the 1980s through it" (Eastman, 2000, p.239). The star-power of Abdur Razzak, Kabori Sarwar, Shabana, Farida Akhter Bobita, Farooque, Shabnam, Kohinoor Akhter Shuchanda, Alamgir, Sohel Rana, Bulbul Ahmed,

Zafar Iqbal, Wasim, Ilias Kanchan, Jashim, Rozina, Parveen Sultana Diti, Champa, Salman Shah, Shabnoor, Riaz, Ferdous, Shakib Khan and Purnima is considered another film marketing technique that convinces the audience to watch films in the theatre. Others poster-based methods of film marketing were banner, leaflet, lobby card, press card, a newspaper advertisement and magazine advertisement (Hossain \& Sultana, 2016).

Another film marketing technique called microphone publicity also used the sign. Microphone publicity is referred to as a van with sound system-fully covered with film poster - used to travel various areas and a narrator in it supposed to announce the news of films (Moti, 2016). The van puller drove the van in different regions and the narrator exaggeratedly pronounced.

"Asiteche! Asiteche!" are the Bengali words (means "coming soon") used to announce the arrival of new films and to catch the attention of the audience (Nihad, 2013). The narrator provided information likethe names of actor-actress, director, movie-theaters; release date, movie-show time, ticket price etc. (para. 2). This technique of film marketing was influential among the audience. Film songs were also played in the van to attract audience about the film (Moti, 2016).

Film-songs played on various radio showswere a powerful film marketing technique to convince the audience. In 1927, state-owned radio station, Bangladesh Betar started to broadcast shows- based on upcoming film-songs like - "Onurodher Asor : Ganer Dali", "Tibbet Snow Tarokar Sondhane", "Clinic Plus Surer Dipti", "Sunlight Sangeetmala", "Rokomari Ganer Onusthan Geetali" etc. (Muktadir, 2012). Before playing the song, the host of the show used to state the names of the singer, musician, songwriter along with the name of the film and its release date, actor-actress, director; available movie-theatres; movie-show time etc. (para.4). Influenced by these film-songs played on Radio shows, the audience becomes curious to watch that film in a movie theatre.

Along with state-owned radio stationBangladesh Betar, private organizations for Frequency Modulation broadcasting (FM Radio) established in September of 2006 (Naushad, 2016). Currently, there are 12 approved FM radio stations and 16 supported community radios in Bangladesh (Protom Alo, 2013, September 16). FM radio stations -Radio Foorti 88.0, Radio Today 89.6, Radio Amar 88.4, ABC Radio 89.2 and Dhaka FM 90.4 etc. - are seen promoting films in several shows. The cast of "Antorjala" film- Parimoni and Zayed Khan- promoted the movie through a radio show "Amar Valobasha" on Radio Amar 88.4. Siam Ahmed and Puja Cherry-The lead cast of the film "Poramon 2"- also promoted the movie through a radio show on Radio Today 89.6. It is explicit whether it is Bangladesh Betar or FM Radio, both have shows with useful film marketing technique to reach a large number of audience.

Another film marketing technique that reaches to a large number of audience was 'Chaya Chondo'-a popular show of film-songs broadcasted in the stateowned television channel Bangladesh Television (B.T.V.) in 1964 (Zahid, 2017). This show also provided information like the names of actor-actress, director, available movie-theatres; release date etc. While radio only provided the audio-version of a film-song, television provided the visuals too. That's why the audience loves film marketing done through a TV videos.

Along with, state-owned television channelBangladesh Television (BTV) - the broadcasting of private television channels launched in 1997 (Ashrafi, 2014) and currently, there are 44 approved individual television channels in Bangladesh (Ittefaq, 2018, February 27). Television channels - Ekushe Television (ETV), ATN Bangla, Channel I, News24, Jamuna Television, 71 Television, Bangla vision, Mohona TV, Anondo Television, RTV, Desh Television, Boishkahi Television and NTV - have also promoted the film through their entertainment news bulletin, celebrity talkshow, film-song show etc. "Tarokakothon" in Channel I, "Fair and Lovely Cinema express" in Desh Television, "Cine Hits" in Ekushe Television, "Pran Mango Tarokalap" in RTV, "Cine Beat" in Bangla vision, "Shudhu Cinemar Gan" in Boishkahi Television etc. are famous shows for promoting films through television. So, it is understandable that television-based marketing techniques are also useful for film promotion.

After watching a film, the audience used to involve in the informal and non-commercial conversation among themselves, concerning the positive or negative sides of a movie, is referred as 'Word of mouth' (Hennig Thurau \& Walsh, 2000). Word-of-mouth is one of the trustworthy film marketing techniques for the audience. If 
the audience reaction is positive about a film, more audience will go to watch the movie in the theatre. On the contrary, none will be interested in wasting time and money. In the case of "Aynabaji" and "Dhaka Attack', word-of-mouth has played a decisive role to influence the audience in watching these films.

Once the film has been in theatres for a week, newspapers and magazines started reviewing the film. A positive film-review can be an effective film marketing technique. Newspaper and magazine reviews are critical for sophisticated audiences (Marich, 2009). On the other hand, "television and radio reviews are influential to a lesser extent" (p. 218). Before releasing in theatre, a press meeting for film's marketing where the reporters usually ask questions to the key figures of the cinema. After that, they published salient features of those films in their newspapers, and the audience got attracted to watch that film. Papers (i.e., The Daily Prothom Alo, The Daily Kaler Kontho, The Daily Janakantho, The Daily Star) have an entertainment segment with exciting and exclusive news about film stars and their upcoming films. These also influence the audience a lot.

Above-mentioned traditional film marketing techniques are like a one-way communication between the film content and the audience. On the other hand, contemporary digital media based film marketing techniques are comparatively interactive (Schorr \& Angela, 2003). Datta and Majumder (2014) have credited both traditional and modern tools of film marketing. They encouraged press conferences, launching of music videos, trailers, film websites, merchandising, promotional tours etc. According to the Bangladesh Telecommunication Regulatory Commission (BTRC, 2018), the total number of Internet subscribers has reached 80.829 million at the end of January. So, it's evident that the internet can help film marketing.

Production Houses of Bangladesh are trying to promote their films through the internet. Since 2010, new production houses- Monsoon Films, Jazz Multimedia, and Tiger Media Limited- have started working on the internet-based film marketing techniques. They started their digital film marketing before the release of their films through YouTube Trailer, Teaser, and Facebook campaigning. Producers make YouTube teaser, trailers and create Facebook verified newsgroup of upcoming movies to spread the news of film release. Lead actors also promote their forthcoming film by using their own social media account -Instagram, Twitter, and Facebook.

Another Social media-based film marketing technique is the video news release (VNR) on YouTube. Video news releases (VNRs) are promotional packages offering "full-video news stories featuring aspects of film production as- innovations in special effects, the difficulties of filming in exotic locations and so on" (Eastman, 2000, p. 241). Video news releases (VNRs) have already begun in the YouTube of Bangladesh. Most of them appeared in the "Dekhun video Soho" style, which is far away from 'Eastman's (2000) definition. Thus "negative marketing" which "believes that one of the greatest dangers of advertising is not that of misleading people, but that of boring them to death" (Burnett,2014). Film "Doob" used this technique. "Doob" was based on the famous writer, Humayun 'Ahmed's personal life. The wife of that writer, Mrs Shaon Ahmed accused the director, Mostofa Sarowar Farooque for copyright issues which were denied by him. Some video news released in YouTube like- "Shaon kivabe chup koriye dilo Farooque $k$ Dekhun video soho" or "Farooque Shaon k ki bollen Dekhun video soho", "Farooque k Shaon ki gali dilo Dekhun video soho" etc. The audience has mixed feelings about this marketing technique. Usually, some audience gets attracted to these rumours and go to watch the film in the theatre while some find it annoying.

Websites are another Internet-based film marketing tool. There are two types of film websites typical and official (Madhusudhan, 2012). While the official website is the beginning of more prominent internet marketing, official movie websites allow visitors to view multiple versions of the trailer, watch behind-thescenes interviews. After the success of "Bahubali: The beginning" (2015), fans made a trailer of "Bahubali: The Conclusion" and put it on a typical website of the film. Jago News, Media Vubon, Dhallywood24, BD Arts, and Bangla Tribune- are active news sources of Dhallywood films that influence the audience to watch the movie in the theatre.

Merchandising, as a film marketing technique, is taking place in Bangladesh gradually. "Merchandising refers to creating or licensing others to create merchandise based on a movie" (Eastman, 2000, p. 245) as I have seen in the film "Akti Cinemar Golpo" (2018). "Jui" coconut oil was the title sponsor of that film. The lead actress Rituporna Sen used "Jui" coconut oil in several scenes. One informant of my research bought that oil, also the ticket of that film. So it can be said that this marketing technique influenced the audience.

Promotional tie-ins are a cost-effective marketing technique that involves linking one products facility with others, and it is also taking place in Bangladesh gradually. As my informants mentioned, directors or producers like to make a tie-in between their film and its sequel. The film

"Most welcome" gave a hint of "Most Welcome 2", "Dhaka Attack" has also provided suggestions for its sequel "Dhaka Attack 2". Usually, these patterns of film marketing made a curiosity among the audience to wait for the next attraction.

Films produced by Impress Telefilms (production house), promote with its affiliations like - The Daily Prothom Alo (Newspaper), Channel I (television channel), Meril (cosmetic brand) and Dhaka FM 90.4. 
(Radio station). "Darucini Dip" the film directed by Toukir Ahmed, was a production of Impress Telefilm. This films world-television premiere launched in "Channel I" and the news was covered by the Daily Prothom Alo and Dhaka FM 90.4. It turned as an example of marketing through promotional tie-ins.

Whether 'sit's small or big, every Hollywood production house has a public relation officer with his team to deal with the pre-film marketing plan. The practice of pre-marketing policy is rare in our production houses, except Monsoon Films, Jazz Multimedia, and Tiger Media Limited. Audience Research is an essential part of the pre-marketing plan, to identify the target audience, according to the genre of a film. In Bangladesh, the target audience of the filmmakers like Toukir Ahmed, Tarek Masud, Gias Uddin Selim, and Mustafa Sarwar Farooque is different from the target audience of commercial filmmakers like Kazi Hayat, F. I. Manik, and Mohammad Hannan etc.

Festivals are another place for promoting the film. There are countless festivals domestically and internationally, so finding the right festival depends on the intended audience. These festivals can act as the theatrical premiere or as a marketing tool to hype the upcoming theatrical premiere (Reiss, 2009, p. 139). In Bangladesh, directors like Tarek Masud, Mustafa Sarwar Farooque, Toukir Ahmed and Tanvir Mokammel have exhibited their films internationally in various film festivals. These works as a marketing technique to create a curiosity for the movie in their own country (Masud, 2011). Movies like - Television (2012), Ant Story (2013) did not go for any marketing activities in Bangladesh before its release in foreign countries. These films, after being awarded in a foreign country and audience become curious in Bangladesh to watch these films.

In Hollywood, awards from festivals, such as the Cannes Film Festival and Sundance Film Festival, are used as qualifiers before films reach theatrical release (Eastman, 2000, p. 243). In Bangladesh, the "'National Film Award", "Meril-Prothom Alo Puroskar" etc. are considered as prestigious award shows. Producers make marketing plan with lead actors, their fashion and look, their live performances in these award show. In the 20th Meril-Prothom Alo Award Ceremony, Actress Puja Cherry performed on her new film song to promote the upcoming film "Poramon-2". As I came to know about this film, it will work for others too. To reach audience award shows are an active place for film marketing.

Not only award show performance of stars but also live performances of actors in any platform are also an effective film marketing technique. Siam and Puja, the star cast of the film "Poramon 2", performed live in Jamuna Future Park (a shopping mall of Bangladesh), the audience enjoyed this live celebrity show- and decided to watch that film on -spot.
Another type of live-performance as a film marketing technique is, if stars appeared in live sporting events, people would get to know about upcoming films. The star cast of "Aynabaji" did this in a live sporting event, which was one of the influencing factors, for the audience to watch this film in the theatre.

Theme based promotion of film marketing in Bangladesh is rare. Here comes the example of the film "Lal Tip". Imon and Kushum Shikder, the cast of the film "Lal Tip" executed their film promotion in several universities by distributing Lal Tip (a women fashion object in Bangladesh) among female students.

It is explicit from the discussion above, film marketing techniques in Bangladesh are currently in a state of transition. It's neither completely digital/internetbased nor fully traditional.

b) YouTube Trailer - the most effective film marketing technique

Based on interview data, this study identified that YouTube trailer is the most compelling film marketing technique in Bangladesh. The reason behind it is that- YouTube trailer makes the story of a film predictable so that the audience could judge the film and decide whether to go to watch that film in a theatre or not.

"Trailers must tell a little story, in a limited amount of time to stimulate motivation in viewers, constructed with carefully selected, intriguing cinematic images and compromise an exaggerated extravagance" (Jerrick, 2013, p.2). Trailers are seen on television, YouTube channel of production houses and in the interval of movie-theatres.

Entertainment talk-shows, celebrity live shows, entertainment news bulletins, music channels likeGaan-Bangla; movie channels like - Anondo Television, My TV and Mohona Television etc. uses trailers in Bangladesh.

The production houses can easily measure the audience reaction after uploading a trailer on their YouTube channel. The audience gives their valuable opinion - positive or negative- in the comment box after watching the YouTube Trailer. The trailer of "Aynabaji" (2016) was the biggest hit on YouTube. The audience made positive comments and expressed their desire to watch that film in the theatre- which made a natural assumption of the box-office success of this film. Not only production houses but also actors of related film upload trailers on their personal YouTube channel to promote their films. Shakib Khan, the Super-star of Bangladesh, has also launched his own YouTube channel for promoting his films (Manobzamin, 2018, March 27).

YouTube trailers make the selection of film easier for the audience, as well as give excellent ideas about the commercial success of a film to the 
production houses. So, it is an effective marketing technique for both the audience and the film producers.

\section{COnclusion}

As discussed above, this work is split into two sections, one dealing with film marketing techniques used in Bangladesh (4.1) and one dealing with to identify the most effective film marketing technique in Bangladesh (4.2). A discussion on different film marketing techniques used in Bangladesh has been provided. One of the main contributions of this study is identifying YouTube Trailer as the most effective film marketing technique in Bangladesh. It is effective for several reasons- makes the story predictable by giving audio-visual hints, enables the audience to react instantly at the comment section of YouTube Trailer and gives an advance idea about the commercial success of a film to its production house. Along with YouTube Trailer, several interesting new techniques of film marketing have been found too.

\section{REFERENCES RÉFÉRENCES REFERENCIAS}

1. Abbitt, G. (2014). . Uses and Gratifications Audience Theory. [Video file].Retrieved from https://youtu.be/Nn9 OmTfT3Y

2. Annual Report 2014-2015, (2016). Bangladesh Telecommunication Regulatory Commission. Retrieved from 2016-02.

3. A2z YouTube BD. (2018, June 04). PoraMon2 Siam Ahmed, and Puja Cherry with Soikot Salauddin. [Video file]. Retrieved from https://youtu.be/b rbcWwhRgWU

4. Bagchi, 2080. Arts.bdnews24. Retrieved from https://arts.bdnews24.com/

5. Bandopadhyay \& Alexander, (2017). "Pioneer of Bengali Cinema Hira Lal Sen (in Bengali)"

6. Bandopadhyay \& Samik, (1995). The Early Years of Calcutta Cinema.In Sukanta Choudhury edited: Calcutta, The Living City. Vol II. Calcutta: Oxford University Press. pp. 293-94.

7. Braun, V. and Clarke, V. (2006) Using thematic analysis in Psychology Qualitative Research in Psychology, 3 (2). pp. 77-101. ISSN 1478-0887

Retrieved from: http://eprints.uwe.ac.uk/11735

8. Blumler, J. G., \& McQuail, D. (1969). Television in politics: Its uses and influence: University of Chicago Press.

9. Blumler, J. G., \& Katz, E. (1974). The Uses of Mass Communications: Current Perspectives on Gratifications Research. Sage Annual Reviews of Communication Research Volume III.

10. Bohra, S. A. A. A. (2016). A study on the promotional strategies used by red chilies entertainment pvtltd. Abhinav National Monthly Refereed Journal of Research in Commerce \& Management A, 5, 1-4.
11. Boyce, C., \& Neale, P. (2006). Conducting in-depth interviews: A guide for designing and conducting indepth interviews for evaluation input.

12. Boyd, D. m. \& N. B. Ellison (2007). "Social Network Sites: Definition, History, and Scholarship." Journal of Computer Mediated Communication 13(1): 210230.

13. Burnett, L. (2014). Hulu. CNBC Titans. Retrieved 2014-07-21

14. Chattapadhay, S. C., A. A. . (2014). Aggressive Promotional Campaign: New Avenue of Film Global Media Journal -Indian Edition, 5, 1-3.

15. Cheng, T. (2014). Public Relations and Promotion in Film: How It's Done and Why It's Important.

16. Chisholm \& Brad (1987). "Reading Intertitles". Journal of Popular Film and Television. 15 (3): 137. Doi:10.1080/01956051.1987.9944095.

17. Crossman, A. (2018). Understanding Purposive Sampling: An Overview of the Method and Its Applications. Retrieved from https://www.th oughtco.com/

18. Dasgupta, P. (2017, January 12). "Bangla director focuses on Kolkata and Nawaz for international film". Times of India. Retrieved from: https://timesofindia.indiatimes.com/etimes

19. Department of Youth Development, G. O. t. P. s. R. o. B. (2013). National Youth Policy

20. Dutta, M. D. M., J. . (2014). Marketing Success of the Bengali Films in Recent Years: Study Of Selected Bengali Films International. Journal of Management Research, 2, 259-263.

21. Eastman. S. T. (2000). Orientation to Promotion and research. In S.T. Eastman (Ed.). Research in Media promotion. Mahwah, $\mathrm{NJ}$ : Laurence Erlbaum.

22. Film Marketing. (2018). Retrieved from http://www.filmdaily.tv/marketing/film-marketing

23. Hennig \& Walsh. (2000). Electronic word-of-mouth via consumer-opinion platforms: What motivates consumers to articulate themselves on the Internet. Journal of Interactive Marketing, 18,38-52. https://doi.org/10.1002/dir.10073

24. Hossain, M. M. \& Sultana, T. (2016). Evaluation of Film Posters in Bangladesh. Bangladesh Film Archaive.

25. Internet Subscribers in Bangladesh January. (2018).Bangladesh Telecommunication Regulatory Commission. Retrieved from www.btrc.gov.bd/conte nt/internet-subscribers-bangladeshjanuary-2018

26. International Telecommunication Union (2015). Measuring the Information Society 2015. Geneva: ITU. Retrieved November 30, 2015 from http://www.itu.int/en//TUD/Statistics/Documents/pub lications/misr2015/MISR2015-w5.pdf

27. Jerrick, D. (2013). The Effectiveness of Film Trailers: Evidence from the College Student Market. Journal of Undergraduate Research, XVI. 
https://www.uwlax.edu/urc/juronline/PDF/2013/Jerric k.David.Marketing.pdf

28. Kanapaka, M. (2013). "What is the origin of words Bollywood, Hollywood, Tollywood, Kollywood etc?". From https://www.quora.com/

29. Katz, E., Blumler, J. G., \& Gurevitch, M. (1973). Uses and gratifications research. The Public Opinion Quarterly, 37(4), 509-523.

30. Kotler, P. (2003). Marketing Management 11th Edition, p.472: Prentice-Hall Publishers-Pearson Upper Saddle River, New Jersey.

31. Lasswell, H. D. (1948). The structure and function of communication in society. The communication of ideas, 37, 215-228.

32. Lavrakas, J. P. (2008). Encyclopedia of Survey Research Methods. DOI:http://dx.doi.org/1 0.4135/9781412963947.n531

33. Lorenz, Z. (2011). Uses and Gratifications Theory. Slide Share. Retrieved from https://www.slideshare.net

34. Maguire,M \& Delahunt,B. (2017). "Doing a thematic analysis: A practical, step-by-step guide for learning and teaching scholars." AISHE-J: The All Ireland Journal of Teaching and Learning in Higher Education 9

35. Madhusudhanan. A. (2012). Film Promotion: An Indian Content.

36. Marich \& Robert (2013). Marketing to Moviegoers: A Handbook of Strategies and Tactics (3rd Ed.). Southern Illinois University Press. pp. 54-55.

37. McCall, K. (2002). The REAL Difference between Marketing \& Advertising. Real-World Education for Modern Marketers Retrieved from https://www.marketingprofs.com/

38. Masud, (2011). Film policy in Bangladesh: The Road to Reform. Volume 5. Issue 11. Retrieved from https://archive.thedailystar.net/forum/2011/Novemb er/film.htm

39. Naushad, N. (2016, February 03). The revival of radio. The Daily Star. Retrieved from https://www.thedailystar.net/

40. Patton, M. Q., \& Cochran, M. (2002). A guide to using qualitative research methodology.

41. Medecins Sans Frontiers. Retrieved February, 14, 2014.

42. Qader, M.T. (1993). Bangladesher Chalachitra Shilpa (1st Ed., pp, 74-84). Dhaka, Bangladesh : Bangla Academy

43. Razu, J. (2000). National cinema and the beginning of film history in/of Bangladesh. Retrieved from http://www.screeningthepast.com/

44. Reiss, J. (2010). Think outside the box office: The ultimate guide to film distribution and marketing for the digital era: Hybrid Cinema Publishing.

45. Sannapu. S, Parihar, A. S., Kandwal. G, Kakkar. K. (2014). "Importance of Web Based Tools for Promotion of Movies: A Survey on Indian Movie
Production Houses." International Journal of Online Marketing 4(2) (62): 62-73.

47. Schorr, A. (2003). 1.2 Interactivity: The New Media Use Option State of the Art Angela Schorr. Communication research and media science in Europe: Perspectives for research and academic training in Europe's changing media reality, 57.

48. Steinberg, B. (2016). How Old Media Can Survive in a New World. Wall Street Journal, B1.

49. Stelzer, M. (2011). 2011 Social Media Marketing Industry Report. Retrieved from https://www.social mediaexaminer.com/

50. Tips \& Tools: Coding Qualitative Data. (2012). Retrieved from programeval.ucdavis.edu/ documents/Tips Tools 18 2012.pdf

51. Wheaton, Ken. (2011). Why We Need Less Talking, More Actual Marketing. Ad Age. Retrieved fromhttp://adage.com/article/kenwheaton/talkingact ualmarketing/230678/ 